\title{
NEW DYROSAURID REMAINS (CROCODYLIFORMES, MESOEUCROCODYLIA) FROM THE PALEOCENE OF THE PARAÍBA BASIN, NE BRAZIL
}

\author{
MARIANA VALÉRIA DE ARAÚJO SENA, RAFAEL CÉSAR LIMA PEDROSO DE \\ ANDRADE, RENAN ALFREDO MACHADO BANTIM
}

Programa de Pós-Graduação em Geociências (PPGEOC), Departamento de Geologia, Universidade Federal de Pernambuco. Av. Prof. Moraes Rego, 1235, Cidade Universitária, 50670-901, Recife, PE, Brazil. mari.araujo.sena@gmail.com,rafaclpa@gmail.com,renanbantimbiologo@gmail.com

\author{
JULIANA MANSO SAYÃO
}

Centro Acadêmico de Vitória, Universidade Federal de Pernambuco. Rua Alto do Reservatório, s/nº , Bela Vista, 55608-680, Vitória de Santo Antão, PE, Brazil.jmsayao@gmail.com

\section{JOSÉ ANTONIO BARBOSA}

Laboratório de Geologia Sedimentar e Ambiental (LAGESE), Departamento de Geologia, Universidade Federal de Pernambuco. Av. Prof. Moraes Rego, 1235, Cidade Universitária, 50670-901. Recife, PE, Brazil. barboant@hotmail.com

\section{GUSTAVO RIBEIRO DE OLIVEIRA}

Laboratório de Paleontologia e Sistemática (LAPASI), Departamento de Biologia, Universidade Federal Rural de Pernambuco. Rua Dom Manoel de Medeiros, s/nº, Dois Irmãos, 52171-900. Recife, PE, Brazil.gustavoliveira@gmail.com

\begin{abstract}
The fossil crocodyliforms from the Paraíba Basin in Northeastern Brazil are represented by two species, Hyposaurus derbianus, (uncertain age) and Guarinisuchus munizi, from the Paleocene Maria Farinha Formation. Herein we present new material of a dyrosaurid also collected in deposits of the Maria Farinha Formation, representing cranial, axial and appendicular remains. The specimens are housed at Centro Acadêmico de Vitória, Universidade Federal de Pernambuco (CAV-UFPE) and at Universidade Federal Rural de Pernambuco (UFRPE). The most important contribution of this find is a well-preserved mandibular specimen (CAV 0056-V) with 16 alveoli on the left side and 13 on the right side. Nine complete or partial tooth crowns are preserved, in positions $1-5$. The teeth are conical and homodont with vertical striations. The largest teeth are located at positions $\mathrm{d} 1$ and $\mathrm{d} 4$. The biggest occlusion pits are located between positions $\mathrm{d} 2 \mathrm{and} \mathrm{d} 3$. The seventh alveoli are reduced and close to the eighth alveoli. The mandible, CAV 0056-V, possesses three foramina in the anterior portion of the dentaries and the mandibular symphysis extends to the posterior margins of the d11-d12 dentary alveoli. Based on the features presented in the mandible and the other fossils recovered, we attribute these materials to Dyrosauridae, particularly, to Guarinisuchus cf. G. munizi.
\end{abstract}

Key words: Crocodyliformes, Dyrosauridae, NE Brazil, Paleocene, Paraíba Basin.

RESUMO - Os Crocodyliformes fósseis da Bacia da Paraíba, Nordeste brasileiro, são representados por duas espécies, Hyposaurus derbianus de idade incerta e Guarinisuchus munizi, dos estratos paleocênicos da Formação Maria Farinha. Aqui são apresentados novos materiais de dyrossaurídeo da Formação Maria Farinha, representados por fragmentos craniais, axiais e apendiculares. Os espécimes estão armazenados no Centro Acadêmico de Vitória da Universidade Federal de Pernambuco (CAV-UFPE) e na Universidade Federal Rural de Pernambuco (UFRPE). O novo material contém uma mandíbula bem preservada (CAV 0056-V), com 16 alvéolos do lado esquerdo e 13 do lado direito. Nove coroas dentárias estão preservadas total ou parcialmente completas, nas posições 1-5. Os dentes são homodontes com forma cônica e estrias verticais. Os dentes de maior comprimento estão localizados nas posições d1 e d4. As maiores marcas de oclusão ocorrem entre as posições d2 e d3. Os alvéolos d7 apresentam dimensões reduzidas e ocorrem próximos aos alvéolos d8. A mandíbula, CAV 0056-V apresenta três forames na porção anterior dos dentários e a sínfise mandibular estende-se até a borda posterior dos alvéolos dentários d11-d12. Portanto, fundamentado nas características apresentadas na mandíbula e pelos outros espécimes, nós associamos estes materiais à Dyrosauridae, particularmente, Guarinisuchus cf. G. munizi.

Palavras-chave: Crocodyliformes, Dyrosauridae, NE Brasil, Paleoceno, Bacia da Paraíba.

\section{INTRODUCTION}

Dyrosauridae de Stefano, 1903, is an extinct neosuchian family found possibly as early as the Early-Late Cretaceous boundary (see Young et al., 2016) to early Eocene (Benton \& Clark, 1988; Brochu et al., 2002; Jouve et al., 2005a). These crocodyliforms are found from marine, nearshore (Troxell, 1925; Brochu et al., 2002; Jouve \& Schwartz, 2004; Hill et al., 2015), and freshwater environmental deposits (Buffetaut, 1978; Khosla et al., 2009; Hastings et al., 2010, 2011, 2015).

This family is commonly formed by meso- to longirostrine forms with a mostly tubular rostrum (Scharwarz-Wings, 
2014), except for Cerrejonisuchus improcerus Hastings, Bloch, Cadena \& Jaramillo, 2010 and Anthracosuchus balrogus Hastings, Bloch \& Jaramillo, 2014, from the Paleocene Cerrejón Formation of northeastern Colombia. Phylogenetic analyses of Dyrosauridae have often supported its close relationship with Pholidosauridae (Jouve et al., 2006; Holliday \& Gardner, 2012; Pritchard et al., 2013).

The occurrences of dyrosaurid remains indicate a wide geographic distribution, including Asia (Buffetaut, 1978; Storrs, 1986; Langston, 1995; Khosla et al., 2009), North America (Denton et al., 1997; Shiller et al., 2016), South America (Argollo et al., 1987; Barbosa et al., 2008; Hastings et al., 2010, 2011, 2015; Andrade \& Sayão, 2014), and possibly Europe (Buffetaut \& Lauverjat, 1978). However, most dyrosaurid fossils have been found in Africa (Halstead, 1975; Buffetaut, 1980, 1983; Jouve \& Schwarz, 2004; Jouve, 2005; Jouve et al., 2005a, 2006; Hill et al., 2008; Young et al., 2016).

The development of different feeding strategies and diverse ways of locomotion possibly gave dyrosaurids an advantage over marine reptiles and freshwater crocodyliforms allowing the success of this group as survivors across the $\mathrm{K}$ Pg transition (Barbosa et al., 2008; Andrade \& Sayão, 2014; Hastings et al., 2015; Puértolas-Pascual et al., 2015).

Two species of dyrosaurids have been described from NE Brazil, Hyposaurus derbianus Cope, 1886, with no precise location provided, and Guarinisuchus munizi Barbosa, Kellner \& Viana, 2008, that was found in outcrops of the Maria Farinha Formation, Danian of Poty Quarry, in the coastal zone of the Paraíba Basin (Barbosa et al., 2008; Riff et al., 2012).

Here we describe new material that belongs to Dyrosauridae. All fossils were collected from the same site in the Poty Quarry that the holotype of Guarinisuchus munizi was found (Figure 1). The material is housed in the paleontological collections of Centro Acadêmico de Vitória, Universidade Federal de Pernambuco (CAV-UFPE) and Universidade Federal Rural de Pernambuco (UFRPE), Brazil. The material examined comprises two isolated teeth, an incomplete mandible with articulated dentaries, a dorsal vertebra, an osteoderm, a proximal end of a femur, a proximal end of the right tibia and distal ends of the right and left tibiae. Except for UFRPE 2814, which was collected previously, all fossils were found together forming an association. Therefore, the present analysis focuses on this new dyrosaurid record for the Maria Farinha Formation.

Institutional abbreviations. CAV, Centro Acadêmico de Vitória, Vitória de Santo Antão, Brazil; CNRSTSUNY, Centre National de la Recherche Scientifique et Technologique du Mali, Mali - Stony Brook University, New York, USA; DG-CTG-UFPE, Departamento de Geologia, Centro de Tecnologia e Geociências, Universidade Federal de Pernambuco, Recife, Brazil; IGM, Museo Geológico, at the Instituto Nacional de Investigaciones en Geociencias, Minería y Quimica, Bogotá, Colombia; MNHN, Muséum National d'Histoire Naturelle, Paris, France; MRAC, Musée d'Afrique Centrale, Tervuren, Belgique; NJSM, New Jersey State Museum, Trenton, USA; OCP DEK-GE, Office
Chérifien des Phosphates, Direction de l'Exploitation de Khouribga - Geologie Exploitation, Khouribga, Morocco; UF, Florida Museum of Natural History, University of Florida, Gainesville, USA; UFRPE, Universidade Federal Rural de Pernambuco, Recife, Brazil; UPMC, Université Pierre et Marie Curie, Paris, France; Vb, Laboratoire de Paléontologia des Vertébrés et de Paléontologia Humaine, Université Pierre et Marie Curie, Paris, France; VPL/JU/ IR, Vertebrate Paleontology Laboratory/Jammu University/ intertrappean reptiles, Jammu, India.

\section{GEOLOGICAL SETTING}

The coastal zone of the Paraíba Basin is bounded by the Pernambuco Shear Zone to the south and the Mamanguape High to the north (Barbosa et al., 2003; Barbosa, 2007; Silva et al., 2011). The stratigraphic column of the Paraíba Basin is composed of Cretaceous, Paleocene and Miocene deposits and a variety of Quaternary sediments related to the development of coastal systems (Rossetti et al., 2011, 2012; Lima et al., 2017).

The sedimentary cover of the Paraíba Basin in its coastal zone is not extensive, reaching a maximum thickness of only $400 \mathrm{~m}$ in the region of Itamaracá Island. The coastal region is divided into three main depocenters, Olinda, Alhandra and Miriri, from south to north respectively. The sedimentary filling of this basin is mainly composed of six formations: (1) the Coniacian?/Santonian Beberibe Formation, consisting of continental sandstones, siltstones and claystones (Beurlen, 1967a,b; Muniz, 1993; Barbosa, 2007); (2) the middle Campanian/upper Maastrichtian Itamaracá Formation, consisting of transitional and sandy limestones, marls and dolostones (Beurlen, 1967a,b; Tinoco, 1971; Souza \& Lima Filho, 2005; Moura, 2007); (3) the Maastrichtian Gramame Formation, consisting of marls, limestones and marly limestones from a shallow marine platform (Beurlen, 1967a; Albertão et al., 1994; Gertsch et al., 2013); (4) the Danian Maria Farinha Formation, consisting of limestones, dolostones, marly limestones and sandy limestones formed on a shallow marine platform (Albertão et al., 1994; Stinnesbeck \& Keller, 1995; Keller \& Stinnesbeck, 1996; Koutsoukos, 1998; Barbosa et al., 2003; Barbosa \& Lima Filho, 2006; Barbosa, 2007; Gertsch et al., 2013); (5) the Eocene Tambaba Formation, consisting of dolostones, and limestones deposits formed in reefal-lagoon systems (Correia Filho et al., 2015); and (6) the Miocene Barreiras Formation, consisting of continental sandstones, siltstones and claystones (Rossetti et al., 2011). We adopted the stratigraphic hypothesis of Correia Filho et al. (2015) that proposed the Tambaba Formation as Eocene reefal carbonate deposits that was previously treated as the upper part of the Paleocene Maria Farinha Formation (Beurlen, 1967a).

The specimens treated in this study were collected in deposits of the Maria Farinha Formation. This formation is composed of limestones, marly limestones and thick levels of marls in its lower portion (Barbosa \& Lima Filho, 2006; Nascimento-Silva et al., 2011) (Figure 1). The Maria Farinha 

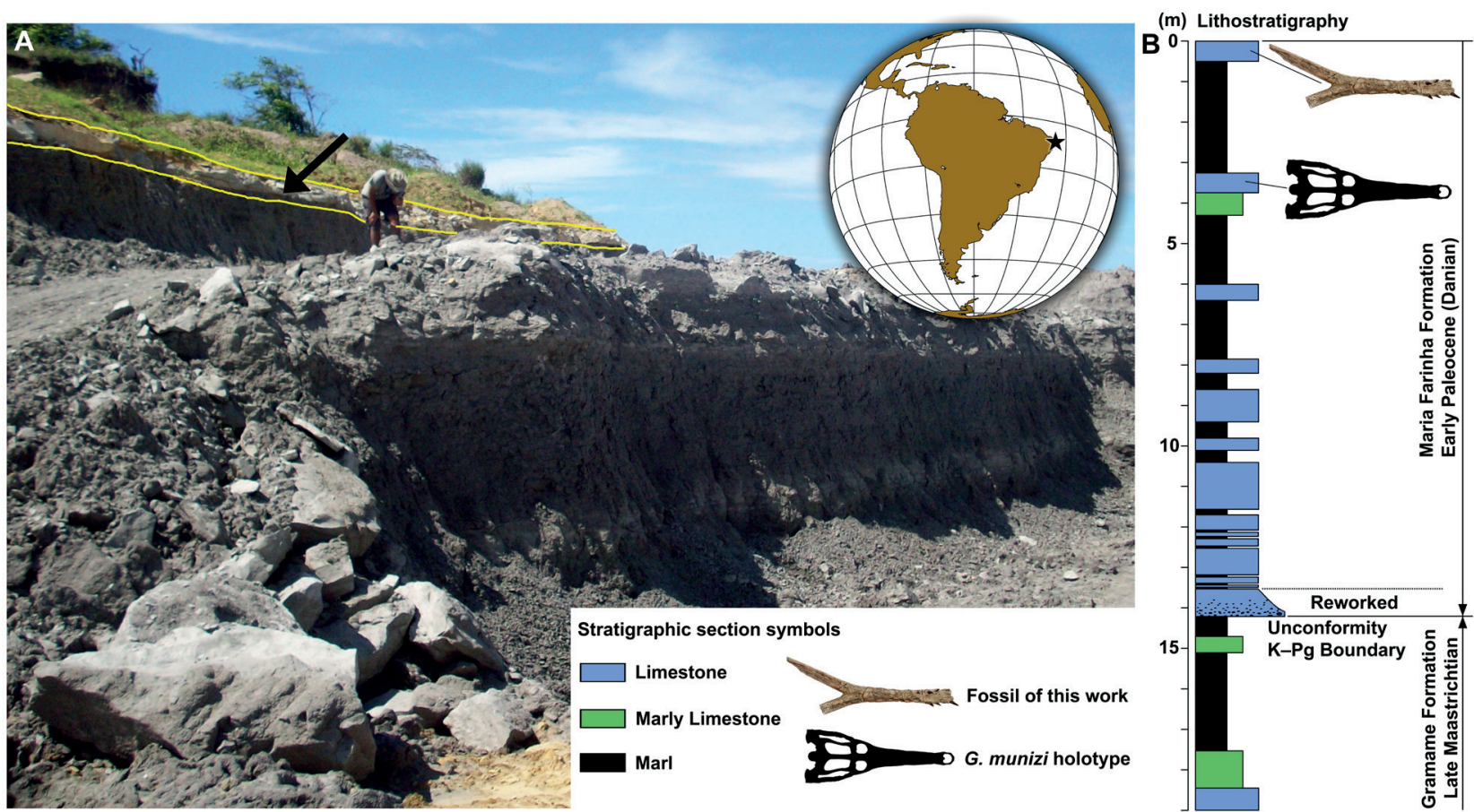

Figure 1. A, location of the Paraíba Basin in the continental platform of northeastern Brazil (black star), and image of the outcrop, including a limestone bed, at the Poty Quarry, Pernambuco State, where the fossil studied in this paper was collected (black arrow). B, stratigraphic section of the Maastrichtian-Paleocene succession exposed in the Poty Quarry. The section shows the position of the fossil discussed in this paper, and the location of the Guarinisuchus munizi holotype that was found at the same site.

Formation was formed during a period of sea level oscillations that affected the Paraíba Basin, and its upper portion exhibits evidence of a regression that affected the record of this unit in the coastal zone (Mabesoone \& Alheiros, 1991; Keller \& Stinnesbeck, 1996; Barbosa \& Lima Filho, 2006; NascimentoSilva et al., 2011).

Fossil vertebrates from the Paraíba Basin have been mentioned in the literature since the end of 19th Century (Cope, 1886; Woodward, 1907; Maury, 1930). The record of fossil reptiles from the Paraíba Basin was first mentioned by Cope (1886), then later by Price (1953a,b; 1957). This group is represented in the basin mostly by marine organisms such as mosasaurs, of which remains were collected in the Itamaracá and Gramame formations, and plesiosaurs (two taxa identified at the family level - Elasmosauridae and Pliosauridae). Elasmosauridae remains were collected in the Itamaracá and Gramame formations while Pliosauridae occurs only in the Itamaracá Formation. Scarce material of one pterosaur was also described from the Gramame Formation, Nyctosaurus lamegoi Price, 1953b. Remains of crocodiles and turtles have been recovered from the Maria Farinha Formation (Price, 1953b; Gallo et al., 2001; Oliveira \& Romano, 2007; Silva et al., 2007; Barbosa et al., 2008; Oliveira \& Deantoni, 2013; Carvalho et al., 2016; Romano, 2016).

\section{SYSTEMATIC PALEONTOLOGY}

CROCODYLOMORPHA Walker, 1970

DYROSAURIDAE de Stefano, 1903

Guarinisuchus Barbosa, Kellner \& Viana, 2008
Guarinisuchus cf. G. munizi Barbosa, Kellner \& Viana, 2008

(Figures 2-4)

Holotype. (DG-CTG-UFPE 5723), Skull and mandible, ulna, cervical and caudal vertebrae, ribs, dermal scutes and isolated teeth.

New referred specimens. Guarinisuchus cf. munizi, partial right postorbital (CAV 0072-V), partial right jugal (CAV 0073$\mathrm{V})$, incomplete mandible (CAV 0056-V), two isolated teeth (CAV 0057-V and CAV 0074-V), osteoderm (CAV 0013-V), partial dorsal vertebra (UFRPE 5142), right proximal femur (CAV 0010-V), right proximal tibia (UFRPE 2814), right distal tibia (CAV 0012-V), left distal tibia (CAV 0011-V).

Geological and geographical procedence. Maria Farinha Formation, Paraiba Basin, Poty Quarry site, region of

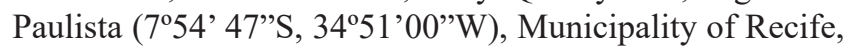
Pernambuco State, Brazil.

Age. Early Paleocene (Late Danian).

\section{DESCRIPTION AND COMPARISON}

Postorbital. The postorbital fragment (CAV 0072-V) measures $60 \mathrm{~mm}$; it is broken and incomplete (Figure 2). It is possible to identify this bone as a part of an anterior portion of the right postorbital, since this bone in Dyrosauridae is very elongated (Barbosa et al., 2008). It has a dorsal surface ornamented by pits and a broad anterior branch with a welldeveloped anterolateral process that constitutes the postorbital spur as observed in an unnumbered specimen described by Buffetaut (1976) and the specimen Vb 602 (currently UPMC) 
in Buffetaut et al. (1990). This feature has not been described by Barbosa et al. (2008) for the holotype of Guarinisuchus munizi. Its anteromedial branch has a rugose depression, probably to meet the frontal (Figure 3A). This depression exhibits in its posterior corner an edge of $90^{\circ}$ that forms the anterolateral margin of the supratemporal fenestra, from there the postorbital becomes slender posteriorly.

Jugal. CAV 0073-V is a right jugal that bears a canal along its medial surface (Figure 3C). Dorsolaterally, it is ornamented with irregularly spaced pits and furrows (Figures 2, 3B). The siphonial foramen is lacking in the medial view in this specimen, as in Guarinisuchus munizi. In contrast to this feature, Rhabdognathus aslerensis Jouve, 2008 (CNRSTSUNY-190) (Brochu et al., 2002) and Cerrejonisuchus improcerus (UF/IGM 29) (Hastings et al., 2010) share the condition of presence of the siphonial foramen in medial view. Mandible. The specimen CAV 0056-V includes dentaries and the splenials, but the articular, angular and surangular bones are not preserved. The mandible is elongated and narrow and it is partially complete; the $\mathrm{d} 1$ to $\mathrm{d} 6$ alveoli are preserved on the left side and the $\mathrm{d} 1$ to $\mathrm{d} 13$ alveoli on the right side (Figures 4A-B). Based on the holotype of Guarinisuchus munizi (DG-CTG-UFPE 5723), it is possible to estimate that a total number of alveoli on each side of the mandible is between 17 and 18 . On the right side of the jaw the d10 alveolus is lacking. Nine complete or partial tooth crowns are preserved in CAV 0056- $\mathrm{V}$, and they are in the positions $\mathrm{d} 1$ to $\mathrm{d} 5$. The first tooth is oriented anterodorsally and the largest teeth are located at positions $\mathrm{d} 1$ and $\mathrm{d} 4$. Likewise, the d4 tooth is the largest in Dyrosaurus phosphaticus Thomas, 1893 (MNHN ALG 3 and MNHN APH 27) (Jouve, 2005) and in Dyrosaurus maghribensis Jouve, Iarochène, Bouya \& Amaghzaz, 2006 (OCP DEK-GE 253), (Jouve et al., 2006). The alveolar edges of $\mathrm{d} 4$ are higher than the edges of the other alveoli. The $\mathrm{d} 7$ alveoli are reduced and close to the eighth alveoli border as described for D. maghribensis (OCP DEKGE 253) (Jouve et al., 2006) and C. improcerus (UF/IGM 29) (Hastings et al., 2010); this pattern was also found in an unidentified dyrosaurid, VPL/JU/IR/400, from Maastrichtian strata in India (Khosla et al., 2009). The tenth alveolus is not preserved on the right side of the dentary. Interalveolar occlusal pits are distributed among the alveoli on the lateral margin of both sides of the mandible, and they are smaller and shallower than the alveoli. The largest diastema is located between $\mathrm{d} 2$ and $\mathrm{d} 3$, probably to fit enlarged $3^{\text {rd }}$ premaxillary teeth (Jouve et al., 2006; Hastings et al., 2010). There are three neurovascular foramina near the medial margin of the third alveoli, two on the left side and one on the right side. One foramen is present on the right side of the holotype of $G$. munizi as well. Nevertheless, it was not possible to confirm the foramina on the left side, since this part was not preserved in the holotype of G. munizi. The symphyseal teeth have broad bases and become narrow towards their apices, as was observed in Acherontisuchus guajiraensis Hastings, Bloch \& Jaramillo, 2011 (UF/IGM 34 and UF/IGM 35). The length of the symphysis in the new mandibular material is $26.51 \mathrm{~cm}$ and posteriorly it reaches the level of the $\mathrm{d} 12-\mathrm{d} 13$ dentary alveoli
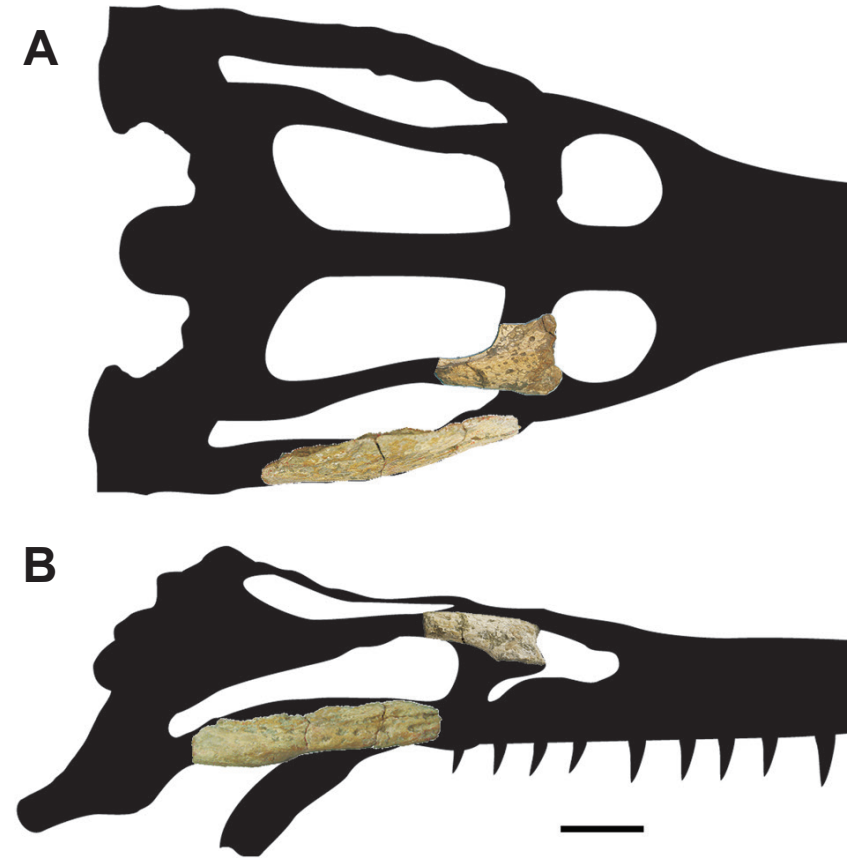

Figure 2. Schematic drawing of the Guarinisuchus munizi skull showing the anatomical positions of the postorbital and jugal fragments described here. Skull in dorsal $(\mathbf{A})$ and in right lateral $(\mathbf{B})$ views. Scale bar $=10 \mathrm{~cm}$.

in the left side. We are unable to assess the total length of the symphysis in the holotype of G. munizi, because the anterior portion in DG-CTG-UFPE 5723 is missing. The symphysis in the holotype of $G$. munizi ends approximately at the position of the $\mathrm{d} 14$ alveolus (Barbosa et al., 2008). In Acherontisuchus guajiraensis the symphysis extends posteriorly to the position of the d17 alveolus in UF/IGM 34, and between the d18 and d19 alveoli in UF/IGM 35 (Hastings et al., 2011). In Arambourgisuchus khouribgaensis Jouve et al., 2005, OCP DEK-GE 18 , the symphysis ends posteriorly at the position of the $\mathrm{d} 16$ tooth. In D. maghribensis, OCP DEK-GE 253, the symphysis reaches, posteriorly, the position of the d17-d21 alveoli (Jouve et al., 2006). In C. improcerus, UF/IGM 30, the mandibular symphysis ends posteriorly at approximately the level of the $\mathrm{d} 9$ alveolus, due to its short snout (Hastings et al., 2010). The symphysis CAV 0056-V is much higher than wider (Figure 5). The width/ratio is similar in CAV 0056-V and other Guarinisuchus specimens. On the posterior surface of the symphyseal border, two depressions are separated by a thin longitudinal bar on the medial surface of the splenials (Figures 4E-F). These depressions constitute the intermandibular foramina, which accommodate the intramandibularis muscle, filling the Meckel's canal (Schwarz-Wings, 2014). The suture between the dentary and splenial forms a depression in dorsal view. In ventral view, the splenial seems to end anteriorly at the position of the $\mathrm{d} 9$ alveolus (Figures 4C-D); in dorsal view it reaches the position of the $\mathrm{d} 8$. In ventral view, it shows a long and narrow anterior process that intercepts the medial borders of the dentaries and constitutes around 35 per cent of the length of the symphysis. The splenial forms 


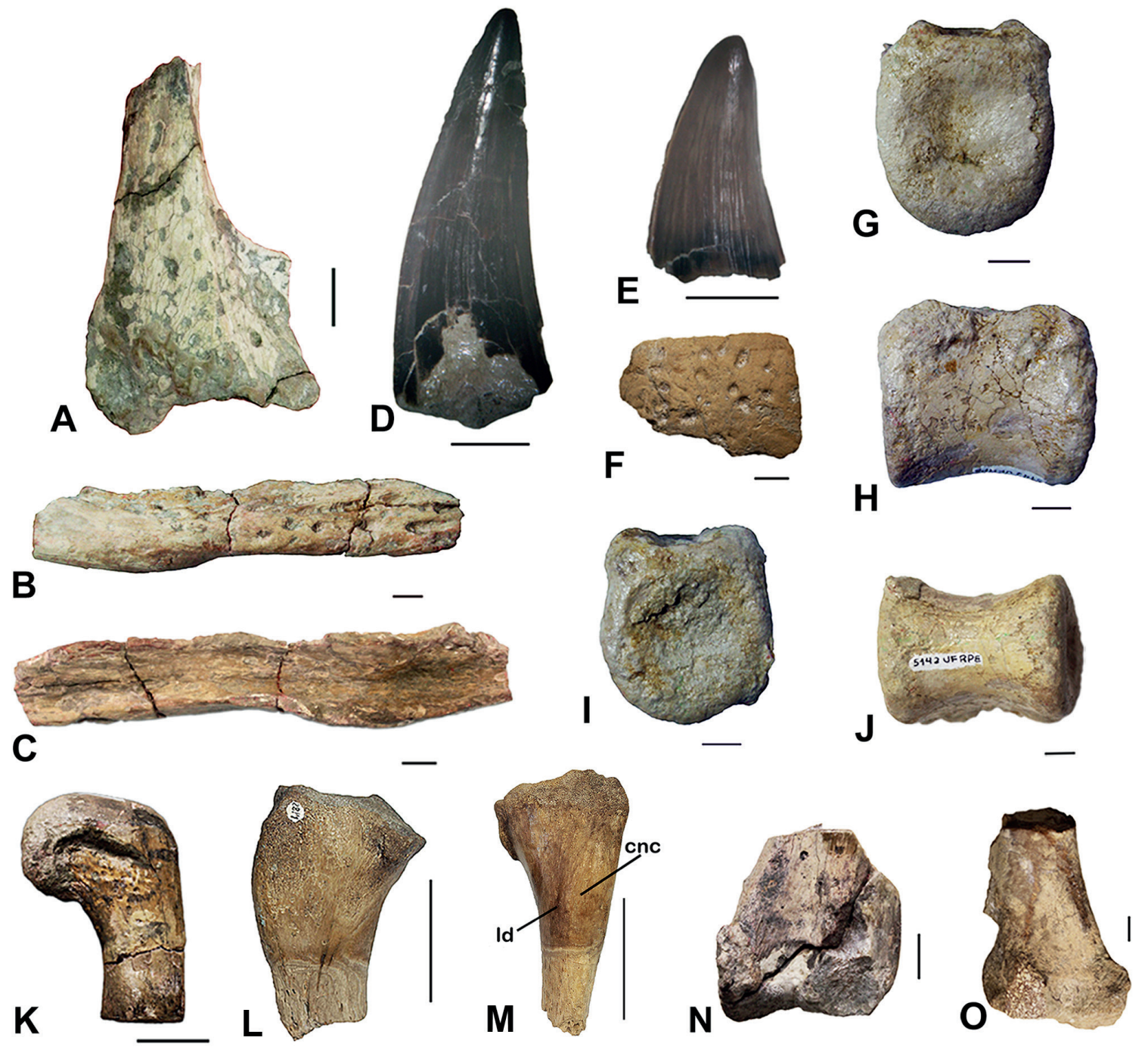

Figure 3. Bone elements of Guarinisuchus munizi. A, right postorbital, CAV 0072-V, in dorsal view; B-C, right jugal, CAV 0073-V, in lateral (B) and medial (C) views; D-E, isolated teeth, CAV 0057-V and CAV 0074-V in lingual view, respectively; $\mathbf{F}$, isolated osteoderm, CAV 0013-V, in dorsal view; G-J, dorsal vertebra, UFRPE 5142, in cranial (G), left lateral (H), caudal (I) and ventral (J) views; K, proximal portion of the right femur, CAV 0010-V, in frontal view; L-M, proximal portion of the right tibia, UFRPE 2814, in anterior and lateral views; N, distal portion of the left tibia, CAV 0011-V, in posterior view; O, distal portion of the right tibia, CAV 0012-V, in posterior view. Abbreviations: cnc, cnemial crest; Id, longitudinal depression. Scale bars: $A-C, F-K, ~ N, O=10 \mathrm{~mm} ; \mathrm{D}, \mathrm{E}=5 \mathrm{~mm} ; \mathrm{L}, \mathrm{M}=50 \mathrm{~mm}$.

the medial edges of the alveoli from the $\mathrm{d} 10$ position to the posterior-most alveolus. In D. maghribensis, OCP DEK-GE 253 , these bones reach anteriorly to the position of the $\mathrm{d} 11$ to d14 teeth (Jouve et al., 2006). Reduction of tooth size, from the anterior to the posterior portion of the mandible, has been described for some dyrosaurids species (Jouve \& Schwartz, 2004; Jouve, 2005; Hastings et al., 2011). Postsymphyseal alveoli are smaller than symphyseal alveoli in the specimen described here as well.

Dentition. CAV 0057-V and CAV 0074-V are two isolated teeth that were found together with the mandible, but they do not fit in any alveolus of the mandible, but their characteristics are identical to the teeth preserved in the mandible. The apicobasal heights of the teeth are $27.31 \mathrm{~mm}$ for CAV 0057 $\mathrm{V}$ and $14.13 \mathrm{~mm}$ for CAV 0074-V; both teeth are conical, elongated and homodont (Figures 3D-E). The teeth have a circular cross section and their labial and lingual surfaces are marked by well-developed, straight carinae. The 'twisted' carina characteristic of Hyposaurus (NJSM 12293) (Denton et al., 1997) is not present. The tooth crowns are posteriorly curved, which is a feature present in other dyrosaurids (Cope, 1886; Barbosa et al., 2008), and they also present a broad base and acute apex. Longitudinal striae are present on both lingual and labial surfaces of isolated teeth as described for Acherontisuchus guajiraensis, UF/IGM 34, (Hastings et al., 2011). In Arambourgisuchus khouribgaensis (OCP DEK-GE 18 and OCP DEK-GE 269) striae are present in some teeth (Jouve et al., 2005a). In Cerrejonisuchus improcerus, UF/ IGM 29, striations were not detected (Hastings et al., 2010). Osteoderm. CAV 0013-V represents an osteoderm not imbricated with a subquadrangular shape. Its dorsal surface is ornamented (Figure 3F) by irregular pits and a smooth ventral surface.

Dorsal vertebra. A single dorsal vertebra was recovered 


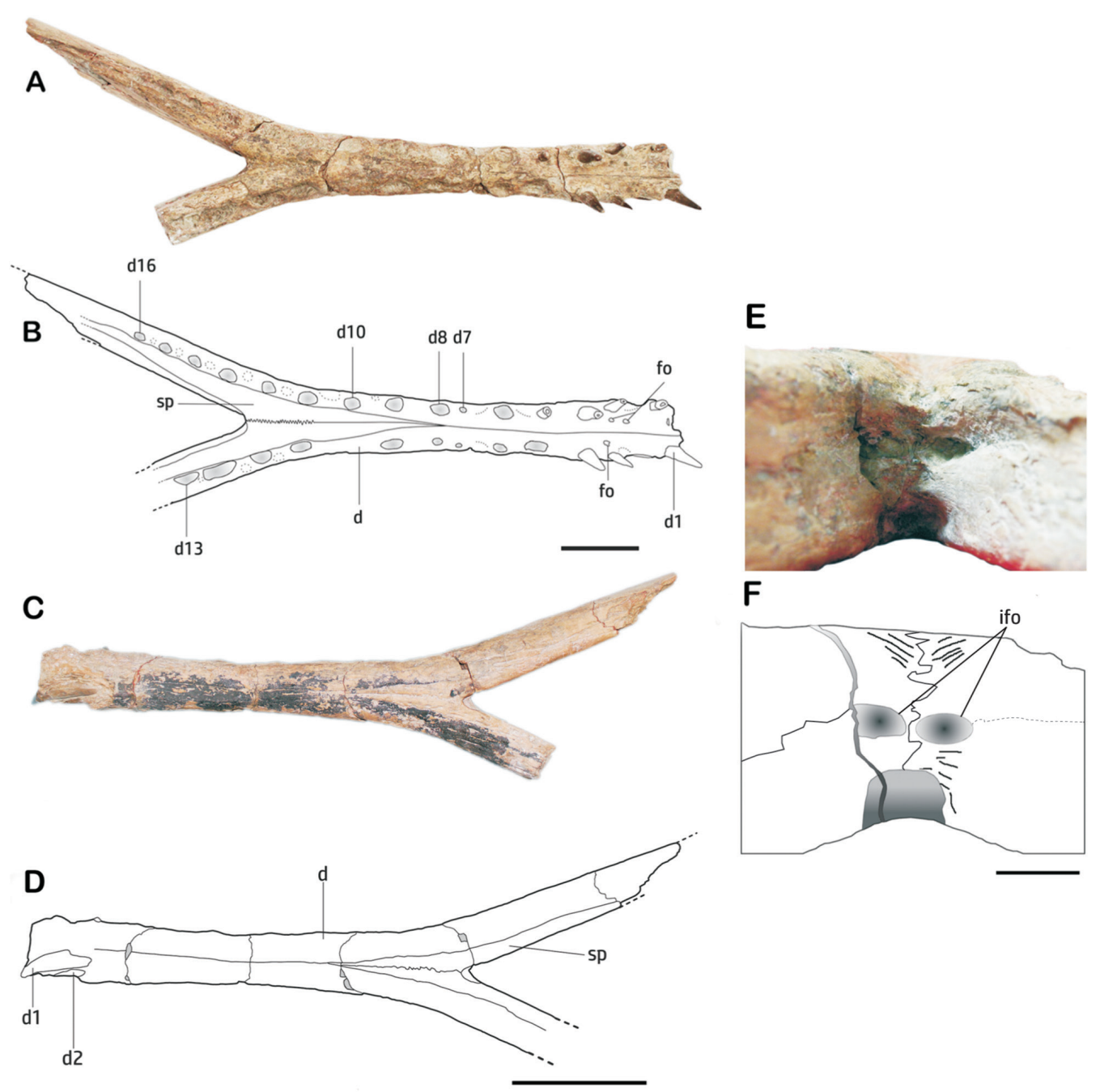

Figure 4. Mandible and its schematic drawing of Guarinisuchus cf. G. munizi CAV 0056-V, in dorsal (A-B), ventral (C-D) and posterior (E-F) views, from the Poty Quarry of the Maria Farinha Formation, Early Paleocene. Abbreviations: d, dentary; d1-16, alveoli of the dentary; fo, foramina; ifo, intermandibular foramina; sp, splenial. Dashed thick lines represent missing bone, dashed thin line represents a probable suture and dotted lines indicate occlusal pits. Scale bars: $A-D=50 \mathrm{~mm} ; E, F=10 \mathrm{~mm}$.

(UFRPE 5142), which has an amphicoelous centrum (Figures $3 \mathrm{G}-\mathrm{J})$. Considering the absence of a hypapophysis in UFRPE 5142 , it is not possible to define the position of the vertebra, although we here tentatively suggest that this piece constitutes a posterior dorsal vertebra probably located between the sixth and fifteenth positions (Jouve et al., 2006), or between the eighth and thirteenth positions (Hastings et al., 2011). In ventral view the width of the central constriction is $31.12 \mathrm{~mm}$ (Figure 3J), similar to the value described for a vertebra UF/ IGM 37 of Acherontisuchus guajiraensis, $32 \mathrm{~mm}$ (Hastings et al., 2011). The centrum height is $48.1 \mathrm{~mm}$, which is 88 per cent of the centrum length $(54.7 \mathrm{~mm})$. In Acherontisuchus guajiraensis, the centrum height corresponds to 71 per cent of the centrum length.

Femur. CAV 0010-V is the proximal end of a right femur (Figure $3 \mathrm{~K}$ ), which expands medially and has a preserved proximodistal length of $58.8 \mathrm{~mm}$. It is laterally compressed with a cranial rounded articular surface forming a joint for the acetabulum. The fourth trochanter is located on the craniomedial surface.
Tibiae. UFRPE 2814 is a proximal epiphysis of a right tibia (Figures $3 \mathrm{~L}-\mathrm{M}$ ) with a diameter that is approximately 58.5 $\mathrm{mm}$. It is bulky and its extremities present a lateral expansion and arched shape, similar to the hyposaurine tibia of CNRSTSUNY 286 (Hill et al., 2015). At the caudolateral edge, there is a protuberance above the articular surface with the fibula, which has been observed in Congosaurus bequaerti (MRAC 1815 and MRAC 1816) (Jouve \& Schwarz, 2004; Schwarz et al., 2006). In lateral view, UFRPE 2814 shows the cnemial crest and a longitudinal depression, probably for insertion of the extensor tendon (Figure 3M). There are slightly longitudinal striations and grooves in the proximal portion. In anterior view, there is a longitudinal depression formed mainly by the articular surface of the epiphysis. There are two tibial distal epiphyses, one corresponding to the left (CAV 0011-V) and the other to the right side (CAV 0012-V) (Figures $3 \mathrm{~N}-\mathrm{O}$ ). In the anterior view, they are convex, with the lateral and medial portions projected posteriorly to form the medial and lateral condyles. The condyles are separated by a longitudinal anterior depression, which forms the articular surface for the astragalus. 


\section{DISCUSSION}

The record of South American dyrosaurids consists of five species found in Brazil and Colombia. The new material can be attributed to a derived dyrosaurid according to the longirostrine jaw; homodont dentition with tooth crowns posteriorly curved and reduced seventh alveolus on the mandible. The specimen CAV 0056-V has seven presplenial dentary alveoli and according to Young et al. (2016) in hyposaurine dyrosaurids this feature varies from nine to fourteen pre-splenial alveoli.

Dyrosaurid taxonomy is extremely dependent on cranial and mandibular features (Halstead, 1975; Jouve, 2005; Jouve et al., 2005b; Jouve, 2007; Hastings et al., 2010, 2011, 2015; Young et al., 2016). Although the comparative material is limited, the present study assigned these fossils to Guarinisuchus cf. G. munizi based on characters of the most well-preserved specimen: the mandible and its dentition. Moreover, the remaining cranial material is very fragmentary and does not preserve most of the diagnostic features. Although there are not enough characters to accomplish a stronger comparison between the holotype and the new specimens, it seems reasonable that the new Maria Farinha Formation findings be ascribed to G. munizi until more fossils become available for the species.

As observed by Jouve \& Schwarz (2004) and Jouve et al. (2006), mandibular features vary according to the size and age of the individual. Furthermore, mandibles are often susceptible to intraspecific variability (Jouve, 2007), and it is difficult to use them as diagnostic characters. The symphysis in CAV 0056-V ends at approximately the d11-d12 alveoli and the dentary of the holotype of G. munizi ends approximately at the level of the $\mathrm{d} 14$ alveolus. We suggest that this difference could be due to individual or ontogenetic variation.

After the description of the Guarinisuchus munizi holotype, no additional material has been formally assigned to this species. The specimens described here were found associated, coming from the same stratigraphic level of the quarry where the G. munizi holotype was found.

The preservation of the anterior portion of the mandible, CAV 0056-V, which is not preserved in the G. munizi holotype, allows for the identification of three foramina on the medial dentary margins. The present record may widen the morphological variation of G. munizi or contribute to a potential new taxon based on more complete specimens.

Data on the width/height ratio of the mandible were plotted for CAV 0056-V and different specimens of Hyposaurus, Congosaurus, Rhabdognathus, Atlantosuchus and Guarinisuchus (Figure 5). CAV 0056-V, G. munizi holotype and other specimens related to G. munizi have the highest mandibles. On the other hand, the mandibles of Hyposaurus specimens are the widest among Dyrosauridae (Salih et al., 2015). The similar width/height ratio values of CAV 0056-V and Guarinisuchus fossils distinguished these specimens from other dyrosaurids, which corroborate to include the new material as Guarinisuchus.

The reduction of the seventh mandibular alveolus and its close placement to the eighth alveolus represents a dyrosaurid apomorphy described for dyrosaurid remains found in Maastrichtian deposits of India (Khosla et al., 2009). Salih et al. (2015) described this feature in a specimen attributed to Hyposaurus from ?Campanian-Maastrichtian deposits of Sudan. In North America, Denton et al. (1997) mentioned this feature for Hyposaurus rogersii found in Danian deposits (Wiest et al., 2016). In the Paleocene of Colombia, Hastings et al. (2010) recorded it for Cerrejonisuchus improcerus, and in the Eocene of Morocco Jouve et al. (2006) recognized it in Dyrosaurus maghribensis.

The long-snouted condition observed in CAV 0056-V is a characteristic of most derived dyrosaurids like Guarinisuchus munizi, which was probably an active hunter of small prey. This is likely due to adaptations of G. munizi and similar dyrosaurids to a semi-aquatic life and fast swimming (Andrade \& Sayão, 2014), and the development of the specialized feeding apparatus of longirostrine dyrosaurids. The tubular rostrum would have created less resistance in water when catching prey. However, this type of rostrum shape is fragile, which restricts potential prey size (SchwarzWings, 2014). Long snouts are an advantage to many crocodiles due to the reduction in hydrodynamic drag for swimming and prey capture (Walmsley et al., 2013). The homodont dentition with acute apices also represents an advantage for catching small prey (Schwarz-Wings, 2014). Some authors proposed that a longirostrine rostrum indicates a piscivorous behavior (Jouve et al., 2006; Hastings et al., 2011), although there is no direct evidence of this relation for dyrosaurids (Schwarz-Wings, 2014). Considering that there is no precise stratigraphic location for Hyposaurus derbianus, the new findings constitute a significant contribution to the Brazilian dyrosaurids, representing the third occurrence in the country. They seem to have been restricted to the Paleocene of Northeast Brazil, and to shallow marine environments. Based on the rostrum morphotypes of Dyrosauridae in South America (Barbosa et al., 2008; Hastings et al., 2010, 2011, 2015), it is possible to conjecture that these animals may have had different feeding behavior and diet, which implies that the group adapted to occupy different niches in Paleocene freshwater and marine environments.

\section{CONCLUSION}

The new material of crocodyliforms from the Danian Maria Farinha Formation in Northeast Brazil is described for the right postorbital and jugal, mandible, isolated teeth, an isolated osteoderm, dorsal vertebra, femur and tibiae.

In the mandible, the seventh alveoli are reduced and close to the eighth alveoli, an important apomorphy of dyrosaurids (Buffetaut, 1976; Jouve et al., 2006). Also, the amount of pre-splenial alveoli is in accordance with that of other described mandibles of hyposaurine dyrosaurids. Based on morphological analysis of the new specimens, we assign these to Guarinisuchus cf. G. munizi, whose holotype was found in the same locality and strata where the new material was collected. 


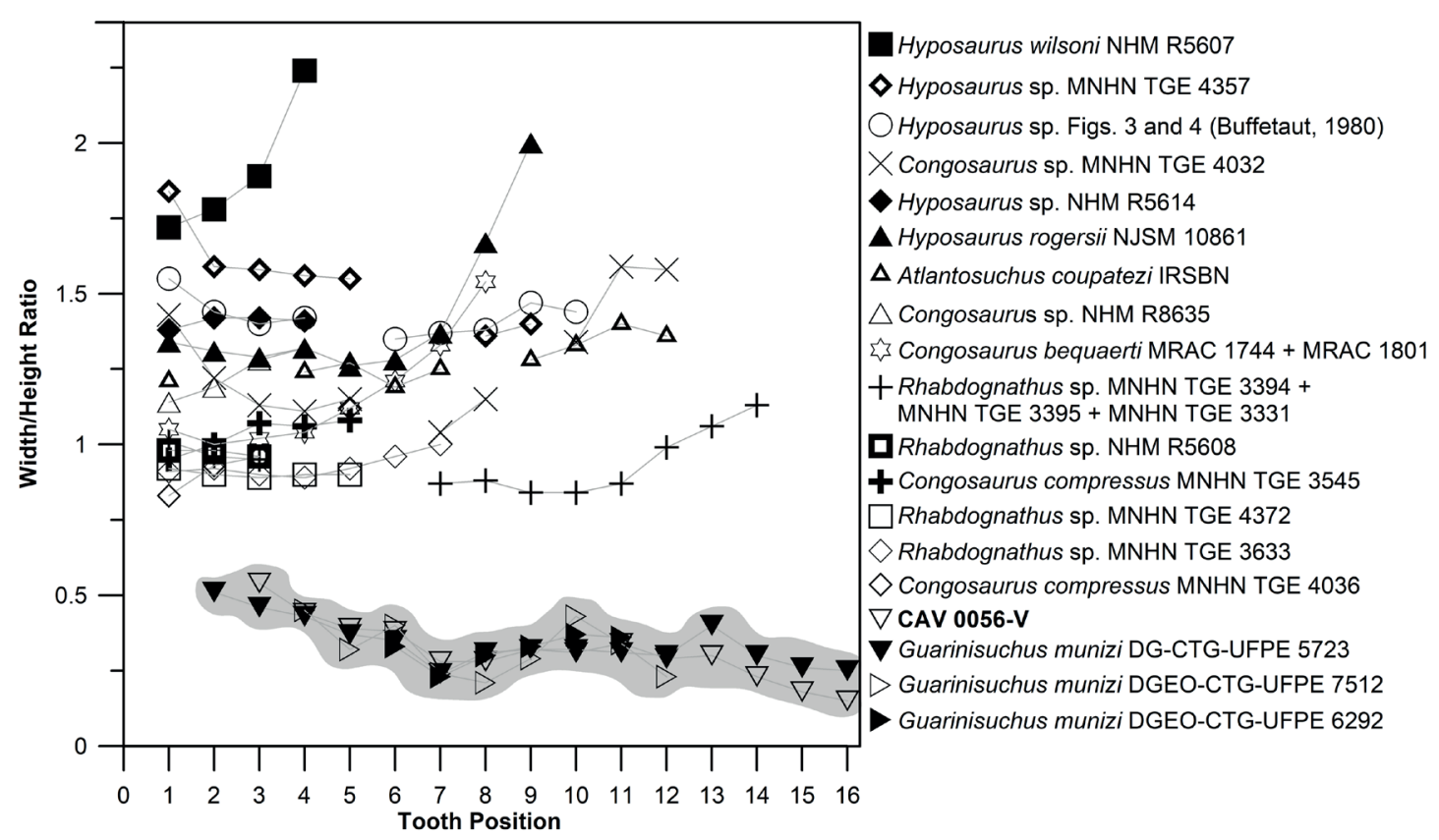

Figure 5. Scatter plot showing width/height ratios along the mandible of Hyposaurus, Congosaurus, Rhabdognathus, Atlantosuchus and Guarinisuchus specimens. Measures taken between the alveoli, according to its position on the mandible. Data for all taxa except CAV 0056-V and other Guarinisuchus munizi specimens are from the study by Jouve (2007).

The new mandibular material, CAV0056-V, preserves the anterior portion which is absent in the Guarinisuchus munizi holotype, and it allowed the identification of the presence of three neurovascular foramina near the medial margin of the third dentary alveoli. Preservation of the mandible, CAV 0056$\mathrm{V}$, verified that the symphyseal length ends at approximately the d11 to $\mathrm{d} 12$ alveoli. The dentary of the G. munizi holotype ends approximately at the $\mathrm{d} 14$ alveolus. We suggest that this variation may be due to individual or ontogenetic variation. However, more contributions based on new materials will be essential to support this assessment. In conclusion, according to the characters described to date, the dyrosaurids from the Danian Maria Farinha Formation were longirostrine forms and probably active hunters of small preys that inhabited the marine environment.

\section{ACKNOWLEDGEMENTS}

We thank A. Barreto, for access to the holotype and other materials referred to Guarinisuchus munizi, and to the collections under her management (DG-CTG-UFPE). We are grateful to F. Pessoa, L. Bacelar, M. Botter and T. Nascimento for their help with photography and schematic drawing and T. Gonçalves for his assistance with the statistics used in this work. The manuscript greatly benefited from the helpful, informed comments from reviewers A. Hastings and S. Jouve. We thank the Laboratório de Geologia Sedimentar e Ambiental (LAGESE) and CNPq for financial support grants to J. Sayão (process numbers 310799/2014-7 and 458164/2014-3), M. Sena (process number 142636/2015-0), R. Andrade (process number 147466/2014-8) and R. Bantim (process number 140555/2013-7).

\section{REFERENCES}

Albertão, G.A.; Koutsoukos, E.A.M.; Regali, M.P.S.; Attrep Jr., M. \& Martins Jr., P.P. 1994. The Cretaceous-Tertiary boundary in southern low-latitude regions: preliminary study in Pernambuco, north-eastern Brazil. Terra Nova, 6:366-375. doi:10.1111/j.13653121.1994.tb00509.x

Andrade, R.C.L.P. \& Sayão, J.M. 2014. Paleohistology and lifestyle inferences of a dyrosaurid (Archosauria: Crocodylomorpha) from Paraíba Basin (northeastern Brazil). PLoS ONE, 9:e102189. doi:10.1371/journal.pone.0102189

Argollo, J.; Buffetaut, E.; Cappetta, H.; Fornari, M.; Herail, G.; Laubacher, G.; Sigé, B. \& Vizcarra, G. 1987. Découverte de vertébrés aquatiques présumés Paléocenes dans les Andes septentrionales des Bolivie (Rio Suches, synclinorium de Puntina). Geobios, 20:123-127. doi:10.1016/S00166995(87)80061-X

Barbosa, J.A. 2007. A deposição carbonática na faixa costeira RecifeNatal, NE do Brasil: aspectos estratigráficos, geoquímicos e paleontológicos. Programa de Pós-graduação em Geociências, Universidade Federal de Pernambuco, Tese de Doutorado, 270 p.

Barbosa, J.A.; Kellner, A.W.A. \& Viana, M.S.S. 2008. New dyrosaurid crocodylomorph and evidences for faunal turnover at the K-P transition in Brazil. Proceedings of the Royal Society B, 275:1385-1391. doi:10.1098/rspb.2008.0110

Barbosa, J.A. \& Lima Filho, M.F. 2006. Aspectos estruturais e estratigráficos da faixa costeira Recife-Natal: observações em dados de poços. Boletim de Geociências da Petrobras, 14:287-306.

Barbosa, J.A.; Souza, E.M.; Lima Filho, M.F. \& Neumann, V.H. 2003. A estratigrafia da Bacia Paraíba: uma reconsideração. Estudos Geológicos, 13:89-108.

Benton, M.J. \& Clark, J.M. 1988. Archosaur phylogeny and the relationships of the Crocodylia. In: M.J. Benton (ed.) The phylogeny and classification of the tetrapods: amphibians, reptiles, birds, Clarendon Press, p. 295-338. 
Beurlen, K. 1967a. Estratigrafia da faixa sedimentar costeira RecifeJoão Pessoa. Boletim de Geologia, 16:43-53.

Beurlen, K. 1967b. Paleontologia da faixa sedimentar costeira Recife-João Pessoa. Boletim de Geologia, 16:73-79.

Brochu, C.A.; Bouaré, M.L.; Sissoko, F.; Roberts, E.M. \& O’Leary, M.A. 2002. A dyrosaurid crocodyliform braincase from Mali. Journal of Paleontology, 76:1060-1071. doi:10.1666/00223360(2002)076<1060:ADCBFM>2.0.CO;2

Buffetaut, E. 1976. Une nouvelle definition de la famille des Dyrosauridae de Stefano, 1903 (Crocodylia, Mesosuchia) et ses consequences: inclusion des genres Hyposaurus et Sokotosuchus dans les Dyrosauridae. Geobios, 9:333-336. doi:10.1016/S00166995(76)80037-X

Buffetaut, E. 1978. A dyrosaurid (Crocodylia, Mesosuchia) from the Upper Eocene of Burma. Neues Jahrbuch für Geologie und Paläontologie-Monatshefte, 5:273-281.

Buffetaut, E. 1980. Les crocodiliens Paléogènes du Tilemsi (Mali): un aperçu systématique. Palaeovertebrata, 9:15-35.

Buffetaut, E. 1983. Wounds on the jaw of an Eocene mesosuchian crocodilian as possible evidence for the antiquity of crocodilian intraspecific fighting behavior. Paläontologische Zeitschrift, 57:143-145. doi:10.1007/BF03031756

Buffetaut, E.; Bussert, R. \& Brinkmann, W. 1990. A new non-marine vertebrate fauna in the Upper Cretaceous of northern Sudan. Berliner Geowissenschaftlische Abhandlungen, 120:183-202.

Buffetaut, E. \& Lauverjat, J. 1978. Un crocodilien d'un type particulier dans le Cénomanien de Nazaré. Comptes Rendus Sommaire des Seances de la Societe Géologique de France, 2:79-82.

Carvalho, A.R.; Ghilardi, A.M. \& Barreto, A.M.F. 2016. A new sideneck turtle (Pelomedusoides: Bothremydidae) from the Early Paleocene (Danian) Maria Farinha Formation, Paraíba Basin, Brazil. Zootaxa, 4126:491-513. doi:10.11646/zootaxa.4126.4.3

Cope, E.D. 1886. A contribution to the vertebrate paleontology of Brazil. Proceedings of the American Philosophical Society, 23:1-21.

Correia Filho, O.J.; Alencar, M.L.; Barbosa, J.A. \& Neumann, V.H. 2015. Proposta de formalização da Formação Tambaba, Eoceno da Bacia Paraíba, NE do Brasil. Estudos Geológicos, 25:61-81. doi:10.18190/1980-8208/estudosgeologicos.v25n2p61-81

Denton, R.K.J.; Bobie, J.L. \& Parris, D.C. 1997. The marine crocodilian Hyposaurus in North America. In: J.M. Callaway \& E.L. Nicholls (eds.) Ancient marine reptiles, Academic Press, p. 375-397.

Gallo, V.; Figueiredo, F.; Carvalho, L.B. \& Azevedo, S.A.K. 2001. Vertebrate assemblage from the Maria Farinha Formation after the K-T Boundary. Neues Jahrbuch für Geologie und Paläontologie Abhandlungen, 219:261-284.

Gertsch, B.; Keller, G.; Adatte, T. \& Berner, Z. 2013. The Cretaceous-Tertiary (KTB) transition in NE Brazil. Journal of the Geological Society, 170:249-262. doi:10.1144/jgs2012-029

Halstead, L.B. 1975. Sokotosuchus ianwilsoni n.g., n. sp., a new teleosaur crocodile from the Upper Cretaceous of Nigeria. Journal of Geology and Mining Research, 11:101-103.

Hastings, A.K.; Bloch, J.I.; Cadena, E.A. \& Jaramillo C.A. 2010. A new small short-snouted dyrosaurid (Crocodylomorpha, Mesoeucrocodylia) from the Paleocene of northeastern Colombia. Journal of Vertebrate Paleontology, 30:139-162. doi:10.1080/02724630903409204

Hastings, A.K.; Bloch, J.I. \& Jaramillo, C.A. 2011. A new longirostrine dyrosaurid (Crocodylomorpha, Mesoeucrocodylia) from the Paleocene of north-eastern Colombia: biogeographic and behavioural implications for new-world Dyrosauridae. Palaeontology, 54:1095-1116. doi:10.1111/j.14754983.2011.01092.x
Hastings, A.K.; Bloch, J.I. \& Jaramillo, C.A. 2015. A new bluntsnouted dyrosaurid, Anthracosuchus balrogus gen. et sp. nov. (Crocodylomorpha, Mesoeucrocodylia), from the Palaeocene of Colombia. Historical Biology, 27:998-1020. doi:10.1080/0 8912963.2014.918968

Hill, R.V.; McCartney, J.A.; Roberts, E.; Bouare, M.; Sissoko, F. \& O'Leary, M.A. 2008. Dyrosaurid (Crocodyliformes: Mesoeucrocodylia) fossils from the Upper Cretaceous and Paleogene of Mali: implications for phylogeny and survivorship across the K/T boundary. American Museum Novitates, 3631:119. doi:10.1206/598.1

Hill, R.V.; Roberts, E.M.; Tapanila, L.; Bouaré, M.L.; Sissoko, F. \& O'Leary, M.A. 2015. Multispecies shark feeding in the transsaharan seaway: evidence from Late Cretaceous dyrosaurid (Crocodyliformes) fossils from northeastern Mali. Palaios, 30:589-596. doi:10.2110/palo.2014.109

Holliday, C.M. \& Gardner, N.M. 2012. A new eusuchian crocodyliform with novel cranial integument and its significance for the origin and evolution of Crocodylia. PLOS ONE, 7:e30471. doi:10.1371/journal.pone.0030471

Jouve, S. 2005. A new description of Dyrosaurus phosphaticus (Thomas, 1893) (Mesoeucrocodylia: Dyrosauridae) from the Lower Eocene of North Africa. Canadian Journal of Earth Sciences, 42:323-337. doi:10.1139/E05-008

Jouve, S. 2007. Taxonomic revision of the dyrosaurid assemblage (Crocodyliformes: Mesoeucrocodylia) from the Paleocene of the Iullemmeden Basin, West Africa. Journal of Paleontology, 81:163-175. doi:10.1666/00223360(2007)81[163:TROTDA] 2.0.CO;2

Jouve, S.; Bouya, B. \& Amaghzaz, M. 2005a. A short-snouted dyrosaurid (Crocodyliformes, Mesoeucrocodylia) from the Palaeocene of Morocco. Palaeontology, 48:359-369. doi:10.1111/j.1475-4983.2005.00442.x

Jouve, S.; Iarochene, M.; Bouya, B. \& Amaghzaz, M. 2005b. A new crocodyliform dyrosaurid from the Palaeocene of Morocco and a phylogenetic analysis of Dyrosauridae. Acta Palaeontologica Polonica, 50:581-594.

Jouve, S.; Iarochene, M.; Bouya, B. \& Amaghzaz, M. 2006. A new species of Dyrosaurus (Crocodylomorpha, Dyrosauridae) from the early Eocene of Morocco: phylogenetic implications. Zoological Journal of the Linnean Society, 148:603-656. doi:10.1111/j.1096-3642.2006.00241.x

Jouve, S. \& Schwarz, D. 2004. Congosaurus bequaerti, a Paleocene dyrosaurid (Crocodyliformes; Mesoeucrocodylia) from Landana (Angola). Bulletin de l'Institut Royal des Sciences Naturelles de Belgique, Sciences de la Terre, 74:129-146.

Keller, G. \& Stinnesbeck, W. 1996. Near-K/T age of clastic deposits from Texas to Brazil: impact, volcanism and/or sea-level lowstand? Terra Nova, 8:277-285. doi:0.1111/j.1365-3121.1996. tb00757.x

Khosla, A.; Sertich, J.J.W.; Prasad, G.V.R. \& Verma, O. 2009. Dyrosaurid remains from the intertrappean beds of India and the Late Cretaceous distribution of Dyrosauridae. Journal of Vertebrate Paleontology, 29:1321-1326. doi:10.1671/039.029.0416

Koutsoukos, E.A.M. 1998. An extraterrestrial impact in the early Danian: a secondary $\mathrm{K}-\mathrm{T}$ boundary event? Terra Nova, 10:68-73.

Langston, W.L. 1995. Dyrosaurs (Crocodilia, Mesosuchia) from the Paleocene Umm Himar Formation, Kingdom of Saudi Arabia. Denver, U.S. Geological Survey, p. F1-F36 (Bulletin 2093).

Lima, J.C.F.; Bezerra, F.H.R.; Rossetti, D.F.; Barbosa, J.A.; Medeiros, W.E.; Castro, D.L. \& Vasconcelos, D.L. 2017. Neogene-Quaternary fault reactivation influences coastal basin sedimentation and landform in the continental margin of $\mathrm{NE}$ 
Brazil. Quaternary International, 438:92-107. doi:10.1016/j. quaint.2016.03.026

Mabesoone, J.M. \& Alheiros, M.M. 1991. Base estrutural: faixa sedimentar costeira de Pernambuco, Paraíba e parte do Rio Grande do Norte. Estudos Geológicos, 10:33-43.

Maury, C.J. 1930. O Cretáceo da Parahyba do Norte. Rio de Janeiro, Serviço Geológico e Mineralógico do Brasil, 305 p. (Monografia 8).

Moura, C.R. 2007. Ostracodes da transição entre as formações Itamaracá e Gramame Bacia Paraíba: taxonomia, implicações paleoecológicas, paleoambientais e bioestratigráficas. Programa de Pós-Graduação em Geociências, Universidade Federal de Pernambuco, Dissertação de Mestrado, 101 p.

Muniz, G.C.B. 1993. Novos moluscos da Formação Gramame, Cretáceo Superior dos Estados da Paraíba e de Pernambuco, Nordeste do Brasil. DGEOUFPE. Publicação Especial, 1, 202 p.

Nascimento-Silva, M.V.; Sial, A.N.; Ferreira, V.P.; Neumann, V.H.M.; Barbosa, J.A.; Pimentel, M.M. \& Lacerda, L.D. 2011. Cretaceous-Paleogene transition at the Paraíba Basin, northeastern Brazil: carbon-isotope and mercury subsurface stratigraphies. Journal of South American Earth Sciences, 32:379-392. doi:10.1016/j.jsames.2011.02.014

Oliveira, G.R. \& Deantoni, F.O. 2013. Testudines fósseis do estado pernambucano, o registro mais antigo de Tartarugas da Era Cenozoica do Brasil. In: J.M. Sayão (ed.) Fósseis do litoral norte de Pernambuco: evidências da extinção dos dinossauros, Zoludesign, p. 72-79.

Oliveira, G.R. \& Romano, P.S.R. 2007. Histórico dos achados de tartarugas fósseis do Brasil. Arquivos do Museu Nacional, 65:113-133.

Price, L.I. 1953a. Restos de mosassáurios de Pernambuco e considerações sobre a presença destes répteis na Bacia Amazônica do Brasil. Rio de Janeiro, Divisão de Geologia e Mineralogia, Departamento Nacional de Produção Mineral, p. 1-15 (Notas Preliminares e Estudos 58).

Price, L.I. 1953b. A presença de Pterosauria no Cretáceo Superior do estado da Paraíba. Rio de Janeiro, Divisão de Geologia e Mineralogia, Departamento Nacional de Produção Mineral, p. 1-10 (Notas Preliminares e Estudos 71).

Price, L.I. 1957. A presença de Globidens no Cretácico Superior do Brasil. Rio de Janeiro, Divisão de Geologia e Mineralogia, Departamento Nacional de Produção Mineral, p. 1-24 (Boletim 169).

Pritchard, A.C.; Turner, A.H.; Allen, E.R. \& Norell, M.A. 2013. Osteology of a North American goniopholidid (Eutretauranosuchus delfsi) and palate evolution in Neosuchia. American Museum Novitates, 3783:1-56. doi:10.1206/3783.2

Puértolas-Pascual, E.; Blanco, A.; Brochu, C.A. \& Canudo, J.I. 2015. Review of the Late Cretaceous-Early Paleogene crocodylomorphs of Europe: extinction patterns across the K-Pg boundary. Cretaceous Research, 57:565-590. doi:10.1016/j. cretres.2015.08.002

Riff, D.; Souza, R.G.; Cidade, G.M.; Martinelli, A.G. \& Souza-Filho, J.P. 2012. Crocodilomorfos: a maior diversidade de répteis fósseis do Brasil. Terrae, 9:12-40.

Romano, P.S.R. 2016. The tale of the headless turtle. Zootaxa, 4200:327-330. doi:10.11646/zootaxa.4200.2.7

Rossetti, D.F.; Bezerra, F.H.; Góes, A.M.; Valeriano, M.M.; Andrades-Filho, C.O.; Mittani, J.C.; Tatumi, S.H. \& BritoNeves, B.B. 2011. Late Quaternary sedimentation in the Paraíba Basin, northeastern Brazil: landform, sea level and tectonics in eastern South America passive margin. Palaeogeography, Palaeoclimatology, Palaeoecology, 300:191-204. doi:10.1016/j. palaeo.2010.12.026

Rossetti, D.F.; Góes, A.M.; Bezerra, F.H.; Valeriano, M.M.; Brito-Neves, B.B. \& Ochoa, F.L. 2012. Contribution to the stratigraphy of the onshore Paraíba Basin, Brazil. Anais da
Academia Brasileira de Ciências, 84:313-334. doi:10.1590/ S0001-37652012005000026

Salih, K.A.O.; Evans, D.C.; Bussert, R.; Klein, N.; Nafi, M. \& Müller, J. 2015. First record of Hyposaurus (Dyrosauridae, Crocodyliformes) from the Upper Cretaceous Shendi Formation of Sudan. Journal of Vertebrate Paleontology, 36:e1115408. doi:10.1080/02724634.2016.1115408

Schwarz, D.; Frey, E. \& Martin, T. 2006. The postcranial skeleton of the Hyposaurinae (Dyrosauridae; Crocodyliforms). Palaeontology, 49:695-718. doi:10.1111/j.1475-4983.2006.00563.x

Schwarz-Wings, D. 2014. The feeding apparatus of Dyrosauridae (Crocodyliformes). Geological Magazine, 151:144-166. doi:10.1017/S0016756813000460

Shiller, T.A.; Porras-Muzquiz, H.G. \& Lehman, T.M. 2016. Sabinosuchus coahuilensis, a new dyrosaurid crocodyliform from the Escondido Formation (Maastrichtian) of Coahuila, Mexico. Journal of Vertebrate Paleontology, 36:e1222586. doi:10.1080/02724634.2016.1222586

Silva, M.C.; Barreto, A.M.F.; Carvalho, I.S. \& Carvalho, M.S.S. 2007. Vertebrados e paleoambientes do NeocretáceoDaniano da Bacia da Paraíba. Estudos Geológicos, 17:85-95. doi:10.18190/1980-8208/estudosgeologicos.v17n2p85-95

Silva, M.V.N.; Ferreira, A.N.S.; Neumann, V.H.; Barbosa, J.A.; Pimentel, M.M. \& Lacerda, L.D. 2011. Cretaceous-Paleogene transition at the Paraíba Basin, northeastern Brazil: carbonisotope and mercury subsurface stratigraphies. Journal of South American Earth Sciences, 32:379-392. doi:10.1016/j. jsames.2011.02.014

Souza, E.M. \& Lima Filho, M. 2005. Marco estratigráfico nos arenitos calcíferos (Formação Itamaracá) do Campaniano da Bacia Paraíba à luz da estratigrafia de sequências. Revista de Geologia, 18:61-68.

Stinnesbeck, W. \& Keller, G. 1995. The Cretaceous-Tertiary boundary in southern low-latitude regions: preliminary study in Pernambuco, northeastern Brazil - Comments and reply. Terra Nova, 7:375-382. doi:10.1111/j.1365-3121.1995.tb00807.x

Storrs, G.W. 1986. A dyrosaurid crocodile (Crocodylia, Mesosuchia) from the Paleocene of Pakistan. Postilla, 197:1-16.

Tinoco, I.M. 1971. Foraminiferos e a passagem entre o Cretáceo e o Terciário em Pernambuco. Programa de Pós-graduação em Geociências, Universidade de São Paulo, Tese de Doutorado, $147 \mathrm{p}$.

Troxell, E.L. 1925. Hyposaurus, a marine crocodilian. American Journal of Science, 8:489-514. doi:10.2475/ajs.s5-9.54.489

Walmsley, C.W.; Smits, P.D.; Quayle, M.R.; Mccurry, M.R.; Richards, H.S.; Oldfield, C.C.; Wroe, S.; Clausen, P.D. \& McHenry, C.R. 2013. Why the long face? The mechanics of mandibular symphysis proportions in crocodiles. PLOS ONE, 8:e53873. doi:10.1371/journal.pone.0053873

Wiest, L.A.; Buynevich, I.V.; Grandstaff, D.E.; Terry Jr., D.O.; Maza, Z.A. \& Lacovara, K.J. 2016. Ichnological evidence for endobenthic response to the K-Pg event, New Jersey, USA. Palaios, 31:231-241. doi:10.2110/palo.2015.080

Woodward, A.S. 1907. Notes on some Upper Cretaceous fishremains from the provinces of Sergipe and Pernambuco, Brazil. Geological Magazine, 4:193-197. doi:10.1017/ S0016756800133308

Young, M.T.; Hastings, A.K.; Allain, R. \& Smith, T.J. 2017. Revision of the enigmatic crocodyliform Elosuchus felixi de Lapparent de Broin, 2002 from the Lower-Upper Cretaceous boundary of Niger: potential evidence for an early origin of the clade Dyrosauridae. Zoological Journal of the Linnean Society, 179:377-403. doi:10.1111/zoj.12452

Received in January, 2017; accepted in September, 2017. 